The Canadian Mineralogist

Vol. 42, pp. 797-806 (2004)

\title{
THE CRYSTAL CHEMISTRY OF EPISTOLITE
}

\author{
ELENA SOKOLOVA ${ }^{\S}$ AND FRANK C. HAWTHORNE
}

Department of Geological Sciences, University of Manitoba, Winnipeg, Manitoba R3T 2N2, Canada

\begin{abstract}
The crystal structure of epistolite, ideally $\mathrm{Na}_{4} \mathrm{Nb}_{2} \mathrm{Ti}^{4+}\left(\mathrm{Si}_{2} \mathrm{O}_{7}\right)_{2} \mathrm{O}_{2}(\mathrm{OH})_{2}\left(\mathrm{H}_{2} \mathrm{O}\right)_{4}, a 5.460(1), b$ 7.170(1), $c$ 12.041(2) $\AA$, $\alpha$ 103.63(3), $\beta$ 96.01(3), $\gamma$ 89.98(3) $)^{\circ} V$ 455.4(5) $\AA^{3}$, space group $P \overline{1}, Z=1, D_{\text {calc }} 2.987{\mathrm{~g} . \mathrm{cm}^{-3}}^{-}$from the Ilímaussaq alkaline complex, South Greenland, has been solved by direct methods and refined to $R_{1} 9.8 \%$ on the basis of 1986 unique reflections $\mid F_{\mathrm{o}}$

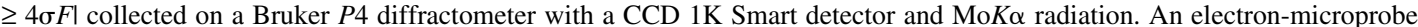
analysis gave (wt.\%): $\mathrm{SiO}_{2} 29.59, \mathrm{Nb}_{2} \mathrm{O}_{5} 31.43, \mathrm{TiO}_{2} 10.24, \mathrm{MnO} 0.34, \mathrm{Fe}_{2} \mathrm{O}_{3} 0.35, \mathrm{Ta}_{2} \mathrm{O}_{5}$ 0.28, $\mathrm{Na}_{2} \mathrm{O} 14.45, \mathrm{CaO} 1.89 \mathrm{~K}_{2} \mathrm{O}$ $0.27, \mathrm{P}_{2} \mathrm{O}_{5}$ 0.36, F 1.32, $\mathrm{H}_{2} \mathrm{O}$ (calculated from structure refinement) 10.46, total 100.43. The empirical formula is $\left(\mathrm{Na}_{3.79} \mathrm{Ca}_{0.27}\right.$ $\left.\mathrm{Mn}_{0.04}\right)_{\Sigma 4.06}\left(\mathrm{Nb}_{1.92} \mathrm{Ti}^{4+}{ }_{0.04} \mathrm{Fe}^{3+}{ }_{0.04}\right)_{\Sigma 2.00} \mathrm{Ti}^{4+}\left(\mathrm{Si}_{2} \mathrm{O}_{7}\right)_{2} \mathrm{O}_{2}\left(\mathrm{OH}_{1.44} \mathrm{~F}_{0.56}\right)\left(\mathrm{H}_{2} \mathrm{O}\right)$, calculated on the basis of $4 \mathrm{Si}(a p f u)$. In the crystal structure, there are two tetrahedrally coordinated sites occupied by $\mathrm{Si}$, with a grand $<\mathrm{Si}-\mathrm{O}>$ distance of $1.617 \AA$. The $\left(\mathrm{SiO}_{4}\right)$ tetrahedra link together to form $\left[\mathrm{Si}_{2} \mathrm{O}_{7}\right]$ groups. There are two octahedrally coordinated $M$ sites. The $M(1)$ site is occupied primarily by $\mathrm{Nb}$ with minor amounts of $\mathrm{Fe}^{3+}$ and $\mathrm{Ti}^{4+}$, with $\left\langle M(1)-\mathrm{O}, \mathrm{H}_{2} \mathrm{O}\right\rangle=2.01 \AA$. The $M(2)$ site is occupied solely by $\mathrm{Ti}^{4+}$, with $\langle M(2)-\mathrm{O}, \mathrm{OH}\rangle=1.962 \AA$. There are three $A$ sites, occupied primarily by Na: the $A(1)$ and $A(2)$ sites are octahedrally coordinated, with $\angle A(1,2)-\mathrm{O}, \mathrm{OH}\rangle=2.39 \AA$, and the $A(3)$ site is [8]-coordinated, with $\left\langle A(3)-\mathrm{O}, \mathrm{OH}, \mathrm{H}_{2} \mathrm{O}\right\rangle=2.57 \AA$. The $A(1)$ site is occupied by $\mathrm{Na}$, the $A(2)$ site is occupied $92 \%$ by $\mathrm{Na}$, and the $A(3)$ site is approximately half-occupied by $\mathrm{Na}: 0.87 \mathrm{Na}+0.82 \square+0.27 \mathrm{Ca}$ $+0.04 \mathrm{Mn}^{2+}$ apfu. The $M(2)$ and $A(1,2)$ octahedra each share six common edges to form a close-packed sheet. This sheet of octahedra is the central part of a TS (titanium-silicate) block. Two adjacent sheets of heteropolyhedra consist of $\left[\mathrm{Si}_{2} \mathrm{O}_{7}\right]$ groups and $M(1)$ octahedra with large hexagonal voids that incorporate [8]-coordinated $A(3)$ polyhedra. A sheet of heteropolyhedra is connected to a sheet of octahedra through vertices of $\left(\mathrm{SiO}_{4}\right)$ tetrahedra, $M(1)$ octahedra and $A(3)$ polyhedra. Within one TS block in epistolite, two $\left[\mathrm{Si}_{2} \mathrm{O}_{7}\right]$ groups, one from each sheet of heteropolyhedra, link to the $M(2)$ octahedron of the central sheet, and sheets of heteropolyhedra are approximately related by a pseudo-mirror plane, $m_{\mathrm{z}}$. The $T S$ blocks repeat along (001) and are connected through hydrogen bonds involving $\left(\mathrm{H}_{2} \mathrm{O}\right)$ groups and acceptor $\mathrm{O}$ atoms of the TS blocks. Previously, the crystal structure of murmanite, ideally $\mathrm{Na}_{4} \mathrm{Ti}^{4+}{ }_{4}\left(\mathrm{Si}_{2} \mathrm{O}_{7}\right)_{2} \mathrm{O}_{4}\left(\mathrm{H}_{2} \mathrm{O}\right)_{4}, a$ 5.383(4), $b$ 7.053(4), $c$ 12.170(3) $⿱ ㇒, \alpha$ 93.16(2), $\beta$ 107.82(2), $\gamma$ $90.06(2)^{\circ}, V 439.14 \AA^{3}$, space group $P 1, Z=1, D_{\text {calc }} 2.86 \mathrm{~g} \mathrm{~cm}^{-3}$, has been considered as a topological analogue of epistolite. It has a TS block as a fundamental building block, but its bond topology is different from that in epistolite. This difference results from different linkages between the central sheet of octahedra and the two adjacent sheets of heteropolyhedra. In murmanite, sheets of heteropolyhedra are shifted relative to each other in the (001) plane. Thus epistolite and murmanite are not isostructural. Murmanite and epistolite are related by the substitution $\mathrm{Ti}^{4+}{ }_{3}+\mathrm{O}^{2-}{ }_{2} \leftrightarrow \mathrm{Nb}^{5+}{ }_{2}+\square+(\mathrm{OH})^{-}{ }_{2}$.
\end{abstract}

Keywords: epistolite, crystal structure, disorder, murmanite, Ilímaussaq alkaline complex, South Greenland.

\section{SOMMAIRE}

Nous avons résolu la structure cristalline de l'épistolite, de formule idéale $\mathrm{Na}_{4} \mathrm{Nb}_{2} \mathrm{Ti}^{4+}\left(\mathrm{Si}_{2} \mathrm{O}_{7}\right)_{2} \mathrm{O}_{2}(\mathrm{OH})_{2}\left(\mathrm{H}_{2} \mathrm{O}\right)_{4}, a 5.460(1)$, $b$ 7.170(1), c 12.041(2) $\AA, \alpha$ 103.63(3), $\beta$ 96.01(3), $\gamma$ 89.98(3),$V$ 455.4(5) $\AA^{3}$, groupe spatial $P \overline{1}, Z=1, D_{\text {calc }} 2.987$ g.cm ${ }^{-3}$, provenant du complexe alcalin d'Ilímaussaq, dans le sud du Groënland, par méthodes directes, et nous l'avons affinée jusqu'à un résidu $R_{1}$ de $9.8 \%$ en utilisant 1986 réflexions uniques $\left|F_{\mathrm{o}} \geq 4 \sigma F\right|$ prélevées avec un diffractomètre Bruker $P 4$ muni d'un détecteur $\mathrm{CCD} 1 \mathrm{~K}$ (rayonnement $\mathrm{MoK} \alpha$ ). Une analyse avec une microsonde électronique a donné (proportions pondérales): $\mathrm{SiO}_{2} 29.59$, $\mathrm{Nb}_{2} \mathrm{O}_{5} 31.43, \mathrm{TiO}_{2}$ 10.24, $\mathrm{MnO} 0.34, \mathrm{Fe}_{2} \mathrm{O}_{3} 0.35, \mathrm{Ta}_{2} \mathrm{O}_{5}$ 0.28, $\mathrm{Na}_{2} \mathrm{O} 14.45, \mathrm{CaO} 1.89 \mathrm{~K}_{2} \mathrm{O}$ 0.27, $\mathrm{P}_{2} \mathrm{O}_{5}$ 0.36, F 1.32, $\mathrm{H}_{2} \mathrm{O}$ (quantité calculée à partir le l'affinement de la structure) 10.46, pour un total de 100.43. La formule empirique est $\left(\mathrm{Na}_{3.79} \mathrm{Ca}_{0.27} \mathrm{Mn}_{0.04}\right)_{\Sigma 4.06}$ $\left(\mathrm{Nb}_{1.92} \mathrm{Ti}^{4+}{ }_{0.04} \mathrm{Fe}^{3+}{ }_{0.04}\right)_{\Sigma 2.00} \mathrm{Ti}^{4+}\left(\mathrm{Si}_{2} \mathrm{O}_{7}\right)_{2} \mathrm{O}_{2}\left(\mathrm{OH}_{1.44} \mathrm{~F}_{0.56}\right)\left(\mathrm{H}_{2} \mathrm{O}\right)$; elle est calculée sur une base de $4 \mathrm{Si}($ apfu $)$. La structure contient de sites tétraédriques qu'occupe le $\mathrm{Si}$, avec une distance globale $<\mathrm{Si}-\mathrm{O}>$ de $1.617 \AA$ Å. Les tétraèdres $\left(\mathrm{SiO}_{4}\right)$ sont agencés en groupes $\left[\mathrm{Si}_{2} \mathrm{O}_{7}\right]$. Il y a deux sites $M$ à coordinence octaédrique. Le site $M(1)$ contient surtout le $\mathrm{Nb}$, avec des quantités moindres de $\mathrm{Fe}^{3+}$ et $\mathrm{Ti}^{4+}$, et $\left\langle M(1)-\mathrm{O}, \mathrm{H}_{2} \mathrm{O}>\right.$ est égal à $2.01 \AA$. Le site $M(2)$ ne contient que le $\mathrm{Ti}^{4+}$, avec $\left.<M(2)-\mathrm{O}, \mathrm{OH}\right\rangle=1.962 \AA$. Il y a trois sites $A$, qui contiennent surtout le Na; les sites $A(1)$ et $A(2)$ ont une coordinence octaédrique, avec $\angle A(1,2)-\mathrm{O}, \mathrm{OH}>=2.39 \AA$, et le site $A(3)$ possède une coordinence [8], avec $<A(3)-\mathrm{O}, \mathrm{OH}, \mathrm{H}_{2} \mathrm{O}>=2.57 \AA$ A . Le site $A(1)$ contient uniquement le $\mathrm{Na}$, le site $A(2)$ en contient à $92 \%$, et le site $A(3)$ est environ à moitié rempli par le Na: $0.87 \mathrm{Na}+0.82 \square+0.27 \mathrm{Ca}+0.04 \mathrm{Mn}^{2+}$ apfu. Les sites

$\S$ E-mail address: elena_sokolova@umanitoba.ca 
octaédriques $M(2)$ et $A(1,2)$ partagent six arêtes communes pour former un feuillet à empilement compact. Ce feuillet d'octaèdres constitue l'élément central d'un bloc TS (à silicate de titanium). Deux feuillets adjacents d'hétéropolyèdres consistent de groupes $\left[\mathrm{Si}_{2} \mathrm{O}_{7}\right]$ et d'octaèdres $M(1)$ parmi lesquels de grosses cavités hexagonales renferment les polyèdres $A(3)$ à coordinence [8]. Un feuillet d'hétéropolyèdres est connecté à un feuillet d'octaèdres par les vertex des tétraèdres $\left(\mathrm{SiO}_{4}\right)$, des octaèdres $M(1)$ et des polyèdres $A(3)$. A l'intérieur d'un bloc $T S$ dans l'épistolite, deux groupes $\left[\mathrm{Si}_{2} \mathrm{O}_{7}\right]$, un de chaque feuillet d'hétéropolyèdres, sont connectés à l'octaèdre $M(2)$ du feuillet central, et les feuillets d'hétéropolyèdres sont grosso modo agencés selon un pseudomirroir $m_{\mathrm{z}}$. Les blocs $T S$ se répètent le long de (001) et sont connectés grâce à des liaisons hydrogène impliquant des groupes $\left(\mathrm{H}_{2} \mathrm{O}\right)$ et des atomes accepteurs d'oxygène des blocs TS. On avait considéré la structure cristalline de la murmanite, de formule idéale $\mathrm{Na}_{4} \mathrm{Ti}^{4+}{ }_{4}\left(\mathrm{Si}_{2} \mathrm{O}_{7}\right)_{2} \mathrm{O}_{4}\left(\mathrm{H}_{2} \mathrm{O}\right)_{4}, a$ 5.383(4), $b$ 7.053(4), $c$ 12.170(3) $\AA$, $\alpha$ 93.16(2), $\beta$ 107.82(2), $\gamma$ 90.06(2),$V 439.14 \AA^{3}$, groupe spatial $P 1, Z=1, D_{\text {calc }} 2.86 \mathrm{~g} \mathrm{~cm}^{-3}$, comme l'analogue topologique de l'épistolite. La murmanite contient aussi le bloc TS comme unité fondamentale, mais la topologie des liaisons diffère de celle de l'épistolite. Cette différence est le résultat d'agencements différents entre le feuillet central d'octaèdres et des deux feuillets adjacents d'hétéropolyèdres. Dans la murmanite, les feuillets d'hétéropolyèdres sont déplacés l'un l'autre dans le plan (001). L'épistolite et la murmanite ne sont donc pas isostructurales. Ces phases sont liées par la substitution $\mathrm{Ti}^{4+}{ }_{3}+\mathrm{O}^{2-}{ }_{2} \leftrightarrow \mathrm{Nb}^{5+}{ }_{2}+\square+(\mathrm{OH})^{-}{ }_{2}$.

(Traduit par la Rédaction)

Mots-clés: épistolite, structure cristalline, désordre, murmanite, complexe alcalin d'Ilímaussaq, Groënland du Sud.

\section{INTRODUCTION}

Epistolite is a low-temperature ( $\mathrm{Nb}-\mathrm{Ti})$-silicate mineral first described from the Ilímaussaq alkaline complex in South Greenland (Bøggild 1901), and then found in the Lovozero alkaline massif, Kola Peninsula, Russia (Semenov et al. 1962). The crystal structure of epistolite was proposed by Khalilov (1965) and Khalilov et al. (1965b: a 5.41, b 7.08, c 12.07 ̊, $\alpha$ 103.1, $\beta$ 96.1, $\gamma 88.0^{\circ}$, space group $P 1$ ), and this version has been the accepted structure of epistolite since then. Khalilov et al. (1965b) presented a drawing of a two-dimensional projection of the crystal structure of epistolite with an $R_{h o l}=22 \%$, but gave no atom coordinates for the structure. Based on the structure of murmanite (Khalilov et al. 1965a, a 5.50, b 7.00, c $11.94 \AA$, $\alpha$ 96, $\beta$ 100.4, $\gamma$ $88.9^{\circ}$, space group $P 1$ ), Khalilov et al. (1965b, Fig. 2) suggested a pattern of cation order in the third dimension of epistolite. Comparison of Figures 1 and 2 of Khalilov et al. (1965b) with Figure 4 of Khalilov et al. (1965a) indicates an epistolite structure with zig-zag chains of edge-sharing $\left(\mathrm{TiO}_{6}\right)$ octahedra alternating with similar chains of $\left(\mathrm{NaO}_{6}\right)$ octahedra. The resulting stoichiometry is in accord with their proposed formula for epistolite, $\mathrm{Na}_{2} \mathrm{Ti}^{4+}{ }_{2}\left[\mathrm{Nb}_{2} \mathrm{O}_{2}(\mathrm{OH})_{4}\right]\left(\mathrm{Si}_{2} \mathrm{O}_{7}\right)_{2}\left(\mathrm{H}_{2} \mathrm{O}\right)_{2}$. More work has been done on the crystal structure of murmanite (Khalilov et al. 1965b, Rastsvetaeva \& Andrianov 1986, Khalilov 1989). Its original chemical formula was given as $\mathrm{Na}_{2} \mathrm{Mn} \mathrm{Ti}^{4+}\left[\mathrm{Ti}^{4+}{ }_{2}(\mathrm{OH})_{4}\right]\left[\mathrm{Si}_{2} \mathrm{O}_{7}\right]_{2}$ $\left(\mathrm{H}_{2} \mathrm{O}\right)_{4}$ (Khalilov et al. 1965b), but has since been changed to $\mathrm{Na}_{4} \mathrm{Ti}^{4+}{ }_{4}\left(\mathrm{Si}_{2} \mathrm{O}_{7}\right)_{2} \mathrm{O}_{4}\left(\mathrm{H}_{2} \mathrm{O}\right)_{4}$ on the basis of a more recent crystal-structure refinement (Khalilov 1989). This later formula is in accord with the analytical work of Karup-Møller (1986b). From the findings of Khalilov (1989), it has been assumed that epistolite and murmanite have the same structure topology, differing only in the distribution of $\mathrm{Ti}^{4+}$ and $\mathrm{Nb}$ over the $M$ sites. In later publications, epistolite has been often con- sidered as a $\mathrm{Nb}$-analogue of murmanite (e.g., EgorovTismenko \& Sokolova 1990, Ercit et al. 1998).

In the 1980s, A.D. Khalilov discussed with ES the possibility of refining the crystal structure of epistolite, but could not find an appropriate single crystal. It is widely known that epistolite does not form single crystals; it occurs as intergrowths with other minerals (Karup-Møller 1986a) or twinned crystals (Ferraris \& Németh 2003). However, the very careful analytical and textural work of Karup-Møller (1986b) is not in accord with the formula proposed by Khalilov et al. (1965b), and Dr. Karup-Møller kindly supplied the best-quality material from his careful study. We emphasize that this material is very difficult to work with, and solution of the crystal structure was a non-trivial enterprise. However, we have obtained a stereochemical model of epistolite that fits the diffraction data tolerably well and is in accord with the available chemical data, and report it here.

\section{EXPERIMENTAL}

\section{Electron-microprobe analysis}

Three crystals of epistolite were analyzed with a Cameca SX-100 electron-microprobe operating in wavelength-dispersion mode with an accelerating voltage of $15 \mathrm{kV}$, a specimen current of $10 \mathrm{nA}$, a beam size of $20 \mu \mathrm{m}$, and count times on peak and background of 2 and $10 \mathrm{~s}$, respectively. The following standards and crystals were used for $K$ or $L \mathrm{X}$-ray lines: F, P: apatite; Na, $\mathrm{Si}$ : tugtupite; $\mathrm{Mg}$ : forsterite; $\mathrm{Ca}$ : diopside; $\mathrm{K}$ : eifelite; $\mathrm{Nb}, \mathrm{Mn}: \mathrm{MnNb}_{2} \mathrm{O}_{6}$; Ti: $\mathrm{TiO}_{2}$; Fe: fayalite; $\mathrm{Zn}$ : gahnite; Sr: strontianite; $\mathrm{Zr}$ : zircon; Ba: barite; Ta: manganotantalite. Data were reduced using the $\phi(\rho \mathrm{Z})$ procedure of Pouchou \& Pichoir (1985). The chemical composition of epistolite is given in Table 1 and is the mean of 10 determinations. The empirical formula (Table 1) was calculated on the basis of $4 \mathrm{Si}$ apfu (atoms per formula 
unit), and the end-member composition is $\mathrm{Na}_{4} \mathrm{Nb}_{2} \mathrm{Ti}^{4+}$ $\left(\mathrm{Si}_{2} \mathrm{O}_{7}\right)_{2} \mathrm{O}_{2}(\mathrm{OH})_{2}\left(\mathrm{H}_{2} \mathrm{O}\right)_{4}$. We did not assign the small amounts of $\mathrm{K}$ and $\mathrm{P}$ in the chemical composition to the empirical formula of epistolite (Table 1), as these constituents may belong to the unidentified submicroscopic phase that has been observed in epistolite crystals from several localities (Karup-Møller 1986a).

\section{Cristal Structure}

A single crystal of epistolite was mounted on a Bruker $P 4$ automated four-circle diffractometer equipped with graphite-filtered $\mathrm{MoK} \alpha \mathrm{X}$-radiation and a Smart 1K CCD detector. The intensities of 4748 reflections with $\overline{6}<h<7, \overline{7}<k<10, \overline{16}<l<16$ were collected to $59.99^{\circ} 2 \theta$ using $30 \mathrm{~s}$ per $0.1^{\circ}$ frame, and an empirical absorption correction (SADABS, Sheldrick 1998) was applied. The refined unit-cell parameters (Table 2) were obtained from 2363 reflections with $I>$ $10 \sigma I$.

On the basis of 1986 unique observed reflections $\left(F_{\mathrm{o}}\right.$ $>4 \sigma F)$, the crystal structure of epistolite was solved and refined with the Bruker SHELXTL Version 5.1 system of programs (Sheldrick 1997) to $R_{1}=9.8 \%$ and a GoF of 1.145. Scattering curves for neutral atoms were taken from the International Tables for Crystallography (1992). $R$ indices are given in Table 2, and are expressed as percentages. Site occupancies for the $M$ and $A$ sites were refined with the scattering curves of $\mathrm{Nb}, \mathrm{Ti}$ and $\mathrm{Na}$. At the last stages of the refinement, three peaks (with magnitudes from 7.6 to $2.5 e^{-}$) were found in the difference-Fourier map, close to the $M(1), S i(1)$ and
Si(2) sites (1.40, 1.58 and $1.32 \AA$, respectively), each shifted from the corresponding site along the $b$ axis. These subsidiary sites were included in the refinement, and their site occupancies were refined with the scattering curves of $\mathrm{Nb}$ and $\mathrm{Si}$, and with $U_{\text {iso }}$ fixed at $0.05 \AA^{2}$. The refined site-occupancies are approximately $10 \%$ of the occupancies at the associated sites. We tried to find coordination polyhedra around these partly occupied cation sites, but had no success. This is not surprising, considering the expected scattering values (approximately $10 \%$ of an $\mathrm{O}$ atom, $\sim 1 e^{-}$) and the high $R$ index of the refinement. The three cation sites with $\sim 10 \%$ occupancy presumably belong to the submicroscopic phase that is intergrown with epistolite ( $c f$. KarupMøller 1986a). Details of the data collection and structure refinement are given in Table 2, final atom parameters for the epistolite structure are given in Table 3 and for the subsidiary sites in Table 4 , selected interatomic distances and angles in Table 5, refined site-scattering values and assigned populations for selected sites are given in Table 6, bond-valence values are given in Table 7, and a proposed scheme of hydrogen bonding is given in Table 8. A table of structure factors may be obtained form the Depository of Unpublished Data, CISTI, National Research Council, Ottawa, Ontario K1A 0S2, Canada.

\begin{tabular}{|c|c|c|c|c|c|}
\hline \multicolumn{4}{|c|}{$\begin{array}{l}\text { itudes from } 7.6 \text { to } 2.5 e^{-} \text {) were found in the } \\
\text { Fourier map, close to the } M(1), \operatorname{Si}(1) \text { and }\end{array}$} & \multicolumn{2}{|c|}{$\begin{array}{l}\text { TABLE 2. MISCELLANEOUS REFINEMENT DATA FOR } \\
\text { EPISTOLITE }\end{array}$} \\
\hline \multirow{8}{*}{\multicolumn{4}{|c|}{$\begin{array}{c}\text { TABLE 1. CHEMICAL COMPOSITION } \\
\text { (w. } \%)^{*} \text { AND UNIT FORMULA (apfu) } \\
\text { FOR EPISTOLITE }\end{array}$}} & $a(\AA)$ & $5.460(1)$ \\
\hline & & & & $b$ & $7.170(1)$ \\
\hline & & & & $c$ & $12.041(2)$ \\
\hline & & & & $\alpha\left({ }^{\circ}\right)$ & $103.63(3)$ \\
\hline & & & & $\beta$ & $96.01(3)$ \\
\hline & & & & y & $89.98(3)$ \\
\hline & & & & $V\left(\AA^{3}\right)$ & $455.4(5)$ \\
\hline & & & & Space group & $P 1$ \\
\hline \multirow{3}{*}{$\begin{array}{l}\mathrm{SiO}_{2} \\
\mathrm{Nb}_{2} \mathrm{O}_{5} \\
\mathrm{TiO}_{2}\end{array}$} & 29.59 & $\mathrm{Si}$ & 4.00 & $z$ & 1 \\
\hline & 31.43 & $\Sigma$ & 4.00 & $\begin{array}{l}\text { Absorption coefficient } \\
\left(\mathrm{mm}^{-1}\right)\end{array}$ & 2.24 \\
\hline & 10.24 & & & & \\
\hline Mno & 0.34 & $\mathrm{Nb}$ & 1.92 & $F(000)$ & 395.0 \\
\hline $\mathrm{Fe}_{2} \mathrm{O}_{3}$ & 0.35 & $\mathrm{Ti}^{4+}$ & 1.04 & $D_{\text {cac. }}\left(\mathrm{g} / \mathrm{cm}^{3}\right)$ & 2.987 \\
\hline $\mathrm{Ta}_{2} \mathrm{O}_{5}$ & 0.28 & $\mathrm{Fe}^{3+}$ & 0.04 & Crystal size (mm) & $0.01 \times 0.10 \times 0.12$ \\
\hline $\mathrm{Na}_{2} \mathrm{O}$ & 14.45 & $\Sigma M$ & 300 & Radiation/ filter & MoKa/graphite \\
\hline $\mathrm{CaO}$ & 189 & & & 28-range for data & 59.99 \\
\hline & 1.00 & & & $R($ int $)(\%)$ & 6.8 \\
\hline $\mathrm{K}_{2} \mathrm{O}$ & 0.27 & $\mathrm{Na}$ & 3.79 & Reflections & 4748 \\
\hline $\mathrm{P}_{2} \mathrm{O}_{5}$ & 0.36 & $\mathrm{Ca}$ & 0.27 & collected & 4033 \\
\hline $\mathrm{F}$ & 1.32 & $\mathrm{Mn}^{2+}$ & 0.04 & Independent reflections & 2495 \\
\hline $\mathrm{H}_{2} \mathrm{O}$ ** & 10.46 & $\Sigma A$ & 4.06 & $F_{0}>40|F|$ & 1986 \\
\hline \multirow[t]{4}{*}{ Total } & 100.43 & $\mathrm{~F}$ & 0.56 & Refinement method & Full-matrix least-squares on $F^{2}$ \\
\hline & & $(\mathrm{OH})$ & 1.44 & Sondnocs of fit on $F^{2}$ & fixed weights proportional to $1 / 0 F_{0}{ }^{2}$ \\
\hline & & (t) & 4 & Goouness of ill ont & 1.140 \\
\hline & & $\left(\mathrm{H}_{2} \mathrm{O}\right)$ & 4 & $\begin{array}{l}\text { Final } R \text { (obs) }(\%) \\
{\left[F_{0}>4 \sigma|F|\right]}\end{array}$ & 9.8 \\
\hline \multicolumn{4}{|c|}{$\begin{array}{l}{ }^{\mathrm{MgO},} \mathrm{ZnO}, \mathrm{SrO}, \mathrm{ZrO}_{2}, \mathrm{BaO} \text { were not } \\
\text { detected; } 0.05 \mathrm{~K} \text { and } 0.04 \mathrm{P}(a p f u) \text { are } \\
\text { attributed to another phase. }\end{array}$} & $R$ indices (all data) $(\%)$ & $\begin{array}{l}R_{1}=12.5 \\
W R_{2}=24.0 \\
G \circ F=1.145\end{array}$ \\
\hline
\end{tabular}




\section{Description of the Structure}

\section{Cation sites}

In the crystal structure of epistolite, there are two tetrahedrally coordinated sites occupied by $\mathrm{Si}$ with a grand $<\mathrm{Si}-\mathrm{O}>$ distance of $1.617 \AA$. There are two octahedrally coordinated $M$ sites. The $M(1)$ site is surrounded by five $\mathrm{O}$ atoms and one $\left(\mathrm{H}_{2} \mathrm{O}\right)$ group, and is occupied primarily by $\mathrm{Nb}$ with minor amounts of $\mathrm{Fe}^{3+}$ and $\mathrm{Ti}^{4+}$ (Table 6) with $\left.<M(1)-\mathrm{O}, \mathrm{H}_{2} \mathrm{O}\right\rangle=2.01 \AA$. The $M(2)$ site is occupied solely by $\mathrm{Ti}^{4+}$ and is coordinated by five $\mathrm{O}$ atoms and an $(\mathrm{OH})$ group with $\langle M(2)-\mathrm{O}, \mathrm{OH}\rangle$ $=1.962 \AA$. There are three $A$ sites, occupied primarily by $\mathrm{Na}$ with minor amounts of $\mathrm{Ca}$ and $\mathrm{Mn}^{2+}$. The $A(1)$ site is octahedrally coordinated by $\mathrm{O}$ atoms and $(\mathrm{OH})$ groups, with $<A(1)-\mathrm{O}, \mathrm{OH}>=2.34 \AA$. The $A(2)$ site is octahedrally coordinated solely by $\mathrm{O}$ atoms with $<A(2)$ $\mathrm{O}>=2.449 \AA$. The $A(3)$ site is [8]-coordinated by six O atoms, one $(\mathrm{OH})$ group and one $\left(\mathrm{H}_{2} \mathrm{O}\right)$ group, with $<A(3)-\mathrm{O}, \mathrm{OH}, \mathrm{H}_{2} \mathrm{O}>=2.57 \AA$. The refined site-scattering value for $A(3)$ is 16.7(6) epfu (electrons per formula unit), indicating that this site is only partly occupied by $\mathrm{Na}$. Based on the chemical analysis (Table 1), we assigned $\mathrm{Ca}$ and $\mathrm{Mn}^{2+}$ to the $A(3)$ site: $0.87 \mathrm{Na}+0.82 \square$ $+0.27 \mathrm{Ca}+0.04 \mathrm{Mn}$ apfu (Table 6).

Examination of Table 6 shows that there are some significant discrepancies between the refined site-scattering values and the corresponding values derived from results of the electron-microprobe analysis. In particular, the $M(1)$ site shows a refined value $(74.5 e)$ much less than that required by the chemical composition derived from the microprobe results $(80.6 e)$. The refined site-scattering values reflect the chemical composition

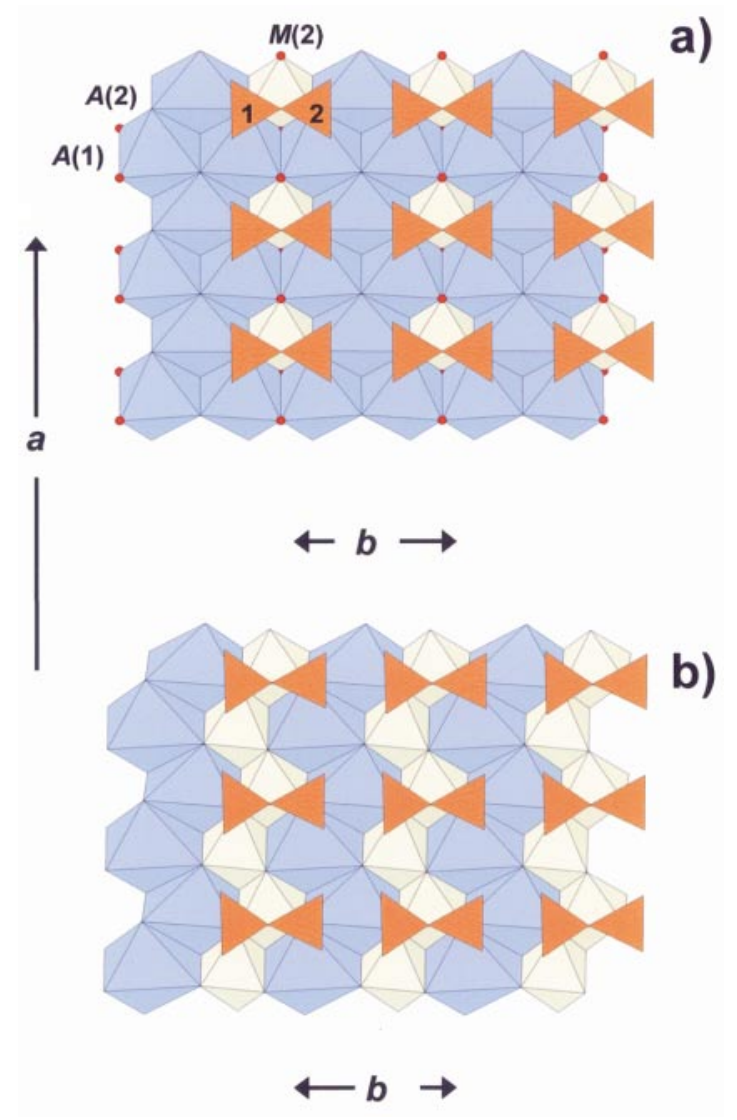

FIG. 1. General view of a sheet of octahedra with adjacent $\left[\mathrm{Si}_{2} \mathrm{O}_{7}\right]$ units in (a) epistolite, and (b) murmanite. $\left(\mathrm{TiO}_{6}\right)$ octahedra are yellow, $\left(\mathrm{NaO}_{6}\right)$ octahedra are blue, $\left(\mathrm{SiO}_{4}\right)$ tetrahedra are orange, $(\mathrm{OH})$ groups are shown as small red circles.

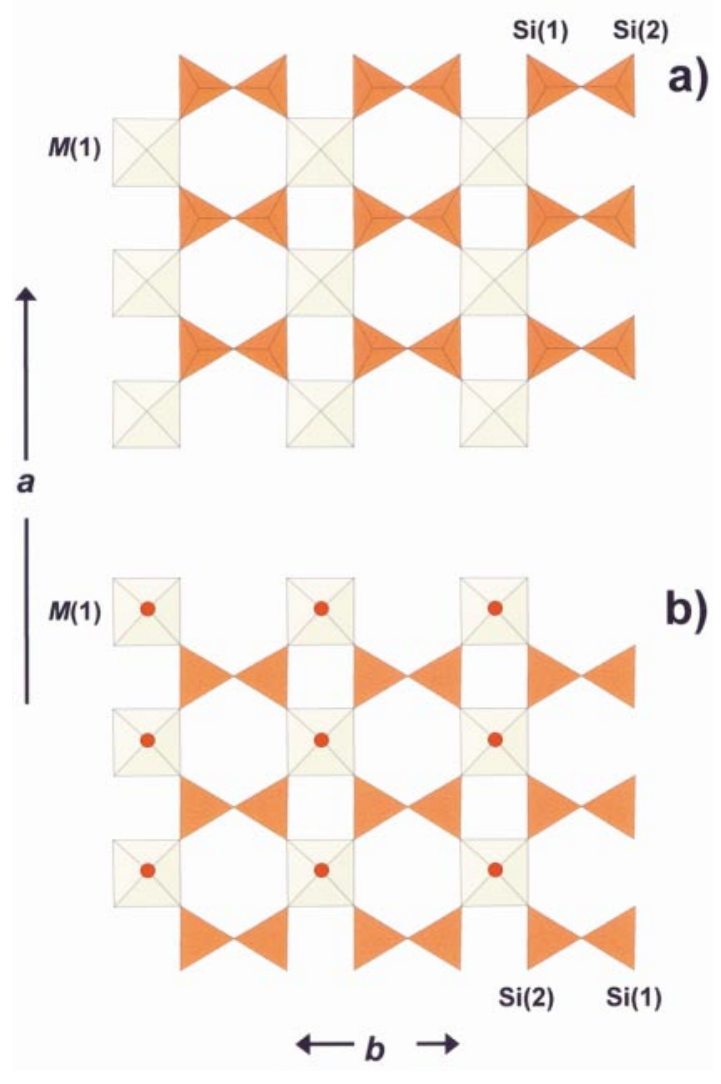

FIG. 2. Linkage of $M(1)$ octahedra and $\left[\mathrm{Si}_{2} \mathrm{O}_{7}\right]$ groups in the sheet of heteropolyhedra in epistolite $[A(3)$ cations are omitted for clarity]: (a) the side facing a sheet of octahedra; (b) the side facing away from the sheet of octahedra. Legend as in Figure 1, $\left(\mathrm{H}_{2} \mathrm{O}\right)$ groups are shown as large red circles. 
of epistolite, whereas the chemical composition incorporates epistolite plus the intergrown phase represented by the $M(1)-, S i(1)$ - and $S i(2)$-satellite peaks in our difference-Fourier map (see above) and the submicroscopic phase intergrown with epistolite that was noted in the very careful work of Karup-Møller (1986a). Hence the observed difference between the two $M(1)$ site-scattering values indicates that the submicroscopic phase is more enriched in heavy species (presumably $\mathrm{Nb}$ and perhaps $\mathrm{Ti}$ ) than epistolite.

\section{Structure topology}

We will describe the crystal structure of epistolite and compare it with that of murmanite to show that their structures are significantly different. In the crystal structure of epistolite, $\left(\mathrm{SiO}_{4}\right)$ tetrahedra link together to form
$\left[\mathrm{Si}_{2} \mathrm{O}_{7}\right]$ groups. The $M(2)\left(=\mathrm{Ti}^{4+}\right)$ and $A(1,2)(=\mathrm{Na})$ octahedra all share six common edges to form a closepacked sheet (Fig. 1a), with an $A: M$ ratio of $3: 1$. In the crystal structure of murmanite, $\mathrm{Ti}^{4+}$ octahedra and $\mathrm{Na}$ octahedra both form edge-sharing brookite-like chains within a sheet of the same topology (Khalilov 1989) (Fig. 1b). The sheet of octahedra is a central part of the TS (titanium silicate) block that is a constituent of several Ti-silicate minerals (Sokolova \& Hawthorne 2001). Two outer parts of the block are heteropolyhedral sheets of $\left[\mathrm{Si}_{2} \mathrm{O}_{7}\right]$ groups and $M(1)$ octahedra (Figs. $2 \mathrm{a}, \mathrm{b}$ ), with large hexagon-shaped interstices that incorporate [8]coordinated $A(3)$ cations. Two heteropolyhedral sheets are connected to a sheet of octahedra via (a) common vertices of $\left(\mathrm{SiO}_{4}\right)$ tetrahedra and $M(2)$ octahedra, and (b) linkage of $M(1)$ and $A(3)$ polyhedra with $A(1)$ and $A(2)$ octahedra (Fig. 3a). The opposite side of the sheet

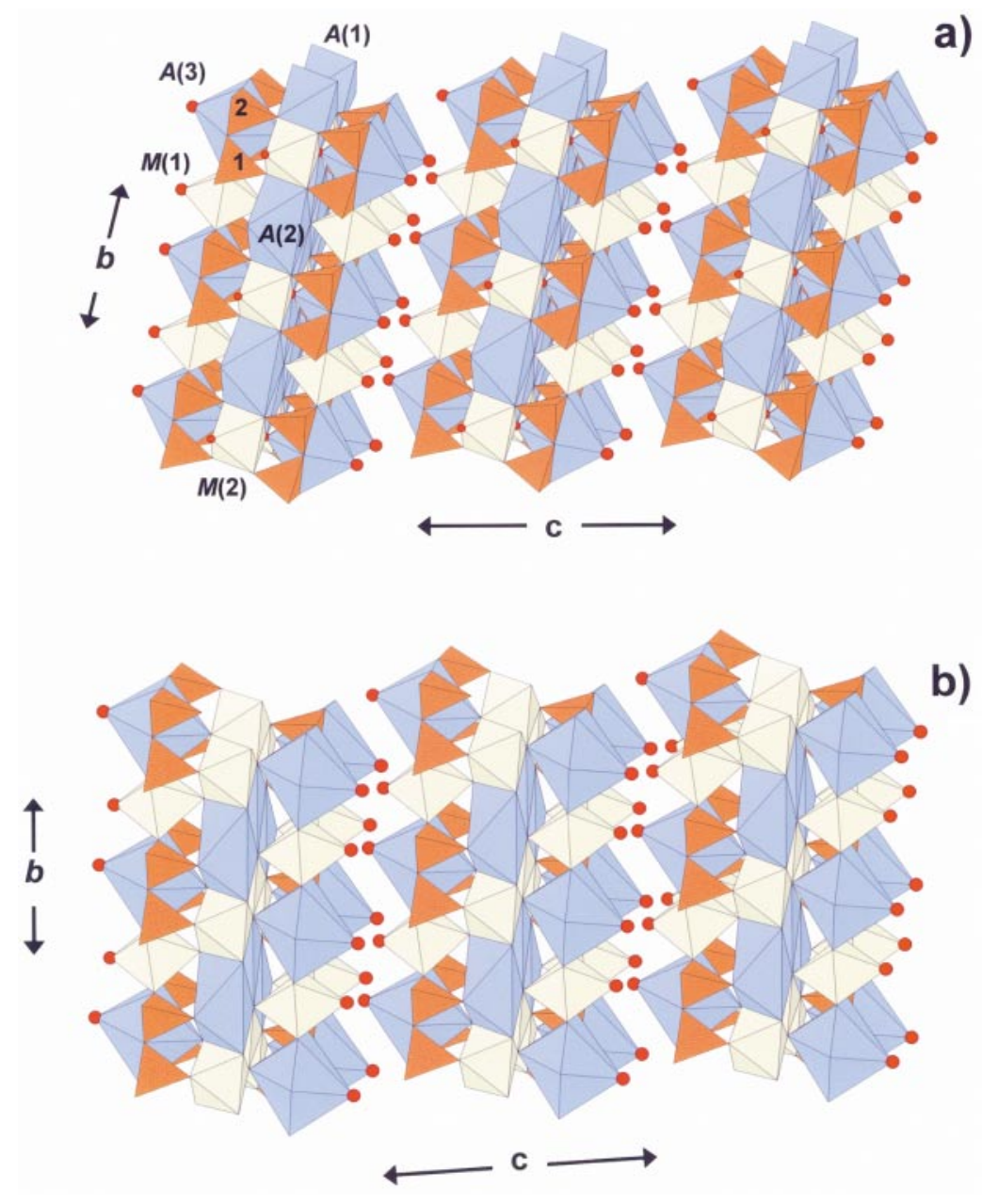

FIG. 3. General view of the crystal structure of (a) epistolite; (b) murmanite. Legend as in Figure 1; [6]- and [8]-coordinated Na polyhedra are blue. 


\begin{tabular}{|c|c|c|c|c|c|c|c|c|c|c|}
\hline & $x$ & $y$ & $z$ & $U_{e q}$ & $U_{11}$ & $U_{22}$ & $U_{33}$ & $U_{23}$ & $U_{13}$ & $U_{12}$ \\
\hline$M(1)$ & $0.7033(2)$ & $0.60465(15)$ & $0.25966(9)$ & $0.0077(4)$ & $0.0061(5)$ & $0.0077(5)$ & $0.0095(5)$ & $0.0028(3)$ & $-0.0004(3)$ & $-0.0008(3)$ \\
\hline$M(2)$ & 0 & 0 & 0 & $0.0175(8)$ & $0.0196(16)$ & $0.0096(14)$ & $0.0217(16)$ & $0.0054(11)$ & $-0.0094(12)$ & $-0.0025(11)$ \\
\hline$A(1)$ & $0.5006(9)$ & $0.2440(7)$ & $-0.0000(4)$ & $0.0178(11)$ & $0.013(2)$ & $0.017(2)$ & $0.024(3)$ & $0.005(2)$ & $0.0033(19)$ & $-0.0009(18)$ \\
\hline$A(2)$ & 0 & $1 / 2$ & 0 & $0.023(3)$ & $0.023(5)$ & $0.023(5)$ & $0.025(5)$ & $0.006(3)$ & $0.012(3)$ & $-0.001(3)$ \\
\hline$A(3)$ & $0.2853(13)$ & $-0.1172(11)$ & $-0.2975(7)$ & $0.026(3)$ & $0.022(4)$ & $0.027(4)$ & $0.027(4)$ & $0.004(3)$ & $0.000(3)$ & $-0.003(3)$ \\
\hline Si(1) & $-0.1954(6)$ & $0.1152(4)$ & $-0.2368(3)$ & $0.0102(7)$ & $0.0106(14)$ & $0.0086(14)$ & $0.0117(14)$ & $0.0034(11)$ & $0.0001(10)$ & $0.0002(10)$ \\
\hline$S i(2)$ & $0.1947(6)$ & $0.3064(4)$ & $0.2364(3)$ & $0.0106(7)$ & $0.0080(14)$ & $0.0093(14)$ & $0.0143(15)$ & $0.0033(11)$ & $-0.0003(10)$ & $-0.0000(10)$ \\
\hline$O(1)$ & $0.4530(17)$ & $0.4206(15)$ & $0.2788(8)$ & $0.0211(19)$ & $0.016(4)$ & $0.020(4)$ & $0.027(5)$ & $0.010(4)$ & $-0.009(3)$ & $-0.014(3)$ \\
\hline$O(2)$ & $0.4546(17)$ & $0.8090(15)$ & $0.2812(9)$ & $0.027(2)$ & $0.014(4)$ & $0.036(6)$ & $0.028(5)$ & $0.006(4)$ & $-0.002(4)$ & $0.006(4)$ \\
\hline$O(3)$ & $0.2084(17)$ & $0.1165(12)$ & $0.2896(7)$ & $0.0175(18)$ & $0.028(5)$ & $0.008(4)$ & $0.019(4)$ & $0.007(3)$ & $0.003(4)$ & $0.000(3)$ \\
\hline$O(4)$ & $0.1597(16)$ & $-0.1589(12)$ & $0.0984(7)$ & $0.0155(\uparrow 7)$ & $0.023(4)$ & $0.012(4)$ & $0.011(4)$ & $0.001(3)$ & $0.004(3)$ & $0.001(3)$ \\
\hline$O(5)$ & $-0.0375(17)$ & $0.4228(14)$ & $0.2861(8)$ & $0.0211(19)$ & $0.018(4)$ & $0.023(5)$ & $0.020(4)$ & $0.002(4)$ & $0.003(3)$ & $0.003(3)$ \\
\hline$O(6)$ & $0.1586(17)$ & $0.2380(12)$ & $0.0971(7)$ & $0.0167\{17\rangle$ & $0.022(4)$ & $0.010(4)$ & $0.018(4)$ & $0.000(3)$ & $0.006(3)$ & $-0.000(3)$ \\
\hline$O(7)$ & $0.0316(18)$ & $0.1933(14)$ & $-0.2897(8)$ & $0.025(2)$ & $0.025(5)$ & $0.028(5)$ & $0.022(5)$ & $0.006(4)$ & $0.007(4)$ & $-0.011(4)$ \\
\hline $\mathrm{O}(8)(\mathrm{OH})$ & $0.2750(13)$ & $-0.0371(11)$ & $-0.0928(7)$ & $0.0103(15)$ & $0.004(3)$ & $0.012(4)$ & $0.015(4)$ & $0.003(3)$ & $0.001(3)$ & $-0.000(3)$ \\
\hline$O(9)$ & $0.6844(16)$ & $0.5436(13)$ & $0.1079(7)$ & $0.0184(18)$ & $0.017(4)$ & $0.024(4)$ & $0.013(4)$ & $0.000(3)$ & $0.003(3)$ & $0.001(3)$ \\
\hline $\mathrm{O}(10)\left(\mathrm{H}_{2} \mathrm{O}\right)$ & $0.736(3)$ & $0.6799(19)$ & $0.4619(10)$ & $0.043(3)$ & $0.056(8)$ & $0.049(7)$ & $0.022(5)$ & $0.002(5)$ & $0.008(5)$ & $0.004(6)$ \\
\hline $\mathrm{O}(11)\left(\mathrm{H}_{2} \mathrm{O}\right)$ & $0.255(3)$ & $-0.263(3)$ & $-0.4825(17)$ & $0.091(6)$ & $0.028(9)$ & $0.173(18)$ & $0.096(13)$ & $0.078(13)$ & $0.010(9)$ & $-0.000(10)$ \\
\hline
\end{tabular}

\begin{tabular}{|c|c|c|c|c|c|}
\hline & $\begin{array}{l}\text { Site } \\
\text { occupancy }\end{array}$ & 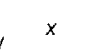 & $y$ & $z$ & $U_{\mathrm{isa}}$ \\
\hline$M(11)$ & 0.1 & $0.700(4)$ & $0.799(3)$ & $0.2568(16)$ & 0.05 \\
\hline$S i(11)$ & 0.1 & $0.447(13)$ & $1.003(10)$ & $0.274(6)$ & 0.05 \\
\hline$S i(21)$ & 0.1 & $0.181(14)$ & $0.490(11)$ & $0.236(6)$ & 0.05 \\
\hline
\end{tabular}

is shown in Figure $2 \mathrm{~b}$ : $\left(\mathrm{H}_{2} \mathrm{O}\right)$ groups of $M(1)$ octahedra and $A(3)$ polyhedra form the outer boundary of the $T S$ blocks. Note that several types of linkages within a $T S$ block have been recently described by Christiansen $e t$ al. (1999).

There is one unique TS block per unit cell in the crystal structures of epistolite (Fig. 3a) and murmanite (Fig. $3 \mathrm{~b}$ ). The blocks repeat along the $c$ direction and are connected by hydrogen bonds between $\left(\mathrm{H}_{2} \mathrm{O}\right)$ groups and $\mathrm{O}$ atoms of adjacent $T S$ blocks. The $T S$ block is a fundamental building block $(F B B)$ for both epistolite and murmanite, but the topologies of the blocks are different in the two structures. This difference results from different linkage of the central sheet of octahedra to adjacent heteropolyhedral sheets. In epistolite, two $\left[\mathrm{Si}_{2} \mathrm{O}_{7}\right]$ groups, one from each heteropolyhedral sheet, link to a single $M(2)$ octahedron of the central sheet, and heteropolyhedral sheets are approximately related by a pseudo-mirror plane (Figs. 4a, 5a). In murmanite, two $\left[\mathrm{Si}_{2} \mathrm{O}_{7}\right]$ groups, one from each heteropolyhedral sheet, link to two distinct octahedra, Ti(2) and Ti(4) (Khalilov 1989) of the brookite-like chain (Fig. 4b). Hence, heteropolyhedral sheets are shifted relative to each other in the (110) plane by about $1.1 \AA$ (Fig. 5b). Thus the bond topology of the TS block is different in epistolite and murmanite, and epistolite and murmanite are not isostructural.

\begin{tabular}{|c|c|c|c|c|}
\hline \multicolumn{5}{|c|}{$\begin{array}{l}\text { TABLE 5. INTERATOMIC DISTANCES }(\AA) \text { AND } \\
\text { ANGLES }\left(^{\circ}\right) \text { FOR EPISTOLITE }\end{array}$} \\
\hline$M(1)-O(1)$ & & $1.968(9)$ & $M(2)-O(4) \times 2$ & $1.971(8)$ \\
\hline$M(1)-O(2)$ & & $1.99(1)$ & $M(2)-O(6) \times 2$ & $1.969(8)$ \\
\hline$M(1)-O(5)$ & & $1.976(9)$ & $M(2)-O(8) \times 2$ & $1.945(7)$ \\
\hline$M(1)-O(7)$ & & $1.99(1)$ & $\langle M(2)-O>$ & 1.962 \\
\hline$M(1)-O(9)$ & & $1.768(8)$ & & \\
\hline \multirow{2}{*}{\multicolumn{2}{|c|}{$M(1)-O(10)$}} & $2.36(1)$ & & \\
\hline & & 2.01 & & \\
\hline$A(1)-O(4)$ & & $2.31(1)$ & $A(3)-O(1)$ & $2.64(1)$ \\
\hline$A(1)-O(6)$ & & $2.31(1)$ & $A(3)-O(2)$ & $2.58(1)$ \\
\hline$A(1)-O(8)$ & & $2.341(9)$ & $A(3)-\mathrm{O}(3) \mathrm{a}$ & $2.76(1)$ \\
\hline$A(1)-O(8) a$ & & $2.333(9)$ & $A(3)-O(3) C$ & $2.71(1)$ \\
\hline$A(1)-O(9)$ & & $2.39(1)$ & $A(3)-O(5)$ & $2.61(1)$ \\
\hline$A(1)-O(9) b$ & & $2.38(1)$ & $A(3)-O(7)$ & $2.61(1)$ \\
\hline \multirow[t]{2}{*}{$\langle A(1)-O\rangle$} & & 2.34 & $A(3)-O(8)$ & $2.40(1)$ \\
\hline & & & $A(3)-O(11)$ & $2.22(2)$ \\
\hline$A(2)-O(4)$ & $\times 2$ & $2.562(8)$ & $\langle A(3)-O\rangle$ & 2.57 \\
\hline$A(2)-O(6)$ & $\times 2$ & $2.543(9)$ & & \\
\hline$A(2)-O(9)$ & $x_{2}$ & $2.243(8)$ & & \\
\hline$\langle A(2)-O\rangle$ & & 2.449 & & \\
\hline$S i(1)-O(2)$ & & $1.61(1)$ & $S i(2)-O(1)$ & $1.604(9)$ \\
\hline $\mathrm{Si}(1)-\mathrm{O}(3)$ & & $1.631(9)$ & $\mathrm{Si}(2)-\mathrm{O}(3)$ & $1.634(8)$ \\
\hline$S i(1)-O(4)$ & & $1.612(9)$ & $S i(2)-O(5)$ & $1.607(9)$ \\
\hline$S i(1)-O(7)$ & & $1.609(9)$ & $\mathrm{Si}(2)-\mathrm{O}(6)$ & $1624(9)$ \\
\hline$\langle\mathrm{Si}(1)-\mathrm{O}\rangle$ & & 1.616 & $\langle\mathrm{Si}(2)-\mathrm{O}\rangle$ & 1.617 \\
\hline \multicolumn{5}{|c|}{$S i(1)-O(3)-S i(2) \quad 135.6(6)$} \\
\hline
\end{tabular}

a: $-x+1,-y,-z ;$ b: $-x+1,-y+1,-z ; c:-x,-y,-z$

Structural formulae for epistolite and murmanite

We may write the structural formulae of these two minerals in terms of the components of their TS blocks. Consider first the sheet of octahedra; as all cation sites are filled in these minerals, these sheets must have the formula $\left[M_{\mathrm{n}} \phi_{2 \mathrm{n}}\right]\left(=\left[M \phi_{2}\right]_{\mathrm{n}}\right)$, where $M$ is any cation and 
TABLE 6. REFINED SITE-SCATTERING VALUES (epfU) AND ASSIGNED SITE-POPULATIONS (apfu) FOR EPISTOLITE

\begin{tabular}{|c|c|c|c|c|c|}
\hline & $\begin{array}{l}\text { Site- } \\
\text { scattering }\end{array}$ & Site population & $\begin{array}{l}\text { Calculated } \\
\text { site-scattering }\end{array}$ & $\underset{\AA}{\langle X-\phi\rangle_{\text {calc. }}}{ }^{*}$ & $\begin{array}{c}\langle X-\phi\rangle_{a b s} \\
\AA\end{array}$ \\
\hline$M(1)$ & $74.5(4)$ & $1.92 \mathrm{Nb}+0.04 \mathrm{Fe}^{3+}+0.04 \mathrm{Ti}^{4+}$ & 80.6 & 2.02 & 2.01 \\
\hline$M(2)$ & $22.0(2)$ & $1.00 \mathrm{Ti}^{4+}$ & 22.0 & 1.99 & 1.962 \\
\hline$A(1)$ & $22.0(3)$ & $2.00 \mathrm{Na}$ & 22.0 & 2.40 & 2.34 \\
\hline$A(2)$ & $10.1(4)$ & $0.92 \mathrm{Na}$ & 10.1 & 2.40 & 2.449 \\
\hline$A(3)$ & $16.7(6)$ & $0.87 \mathrm{Na}+0.82 \mathrm{a}+0.27 \mathrm{Ca}+0.04 \mathrm{Mn}^{2+}$ & 16.0 & 2.54 & 2.57 \\
\hline
\end{tabular}

* ionic radii from Shannon (1976)

\begin{tabular}{|c|c|c|c|c|c|c|c|c|}
\hline & Si(1) & $\operatorname{Si}(2)$ & $M(1)$ & $M(2)$ & $A(1)$ & $A(2)$ & $A(3)$ & $\Sigma$ \\
\hline$O(1)$ & & 1.05 & 0.85 & & & & 0.08 & 1.98 \\
\hline$O(2)$ & 1.03 & & 0.81 & & & & 0.09 & 1.93 \\
\hline$O(3)$ & 0.98 & 0.97 & & & & & $\begin{array}{l}0.07 \\
0.07\end{array}$ & 2.09 \\
\hline$O(4)$ & 1.03 & & & $0.63^{\times 2} \downarrow$ & 0.25 & $\left.0.14^{x^{2}}\right\rfloor$ & & 2.05 \\
\hline$O(5)$ & & 1.04 & 0.84 & & & & 0.08 & 1.96 \\
\hline$O(6)$ & & 0.99 & & $0.64^{\times 2}$ & 0.25 & $0.15^{x^{2}}$ & & 2.03 \\
\hline$O(7)$ & 1.04 & & 0.81 & & & & 0.08 & 1.93 \\
\hline$O(8)$ & & & & $0.68^{\times 2}$ & $0.23^{\times 2}$ & & 0.13 & 1.27 \\
\hline$O(9)$ & & & 1.46 & & $0.21^{12} \mid$ & $0.25^{x^{2}}$ & & 2.13 \\
\hline$O(10)$ & & & 0.34 & & & & & 0.34 \\
\hline$O(11)$ & & & & & & & 0.19 & 0.19 \\
\hline$\Sigma$ & 4.08 & 4.05 & 5.11 & 3.90 & 1.38 & 1.08 & 0.79 & \\
\hline
\end{tabular}

* bond-valence parameters ( $v u$ from Brown (1981)

$\phi$ is any anion. We may write the corresponding formulae as follows: epistolite: $\mathrm{Na}_{3} \mathrm{Ti}^{4+}(\mathrm{OH})_{2} \mathrm{O}_{6}$; murmanite:

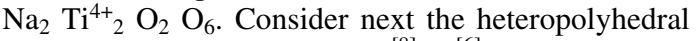
sheet; these have the formula $\left[{ }^{[8]} A_{2}{ }^{[6]} M_{2}\left(\mathrm{Si}_{2} \mathrm{O}_{7}\right)_{2} \phi_{8}\right]$; we have written here the formula of the two heteropolyhedral sheets that constitute a single $T S$ block. We may write the corresponding formulae as follows: epistolite: $\left[{ }^{[8]} \mathrm{Na} \square^{[6]} \mathrm{Nb}_{2}\left(\mathrm{Si}_{2} \mathrm{O}_{7}\right)_{2} \mathrm{O}_{2}(\mathrm{OH})_{2}\left(\mathrm{H}_{2} \mathrm{O}\right)_{4}\right]$; murmanite: $\left[{ }^{[8]} \mathrm{Na}_{2}{ }^{[6]} \mathrm{Ti}^{4+}{ }_{2}\left(\mathrm{Si}_{2} \mathrm{O}_{7}\right)_{2} \mathrm{O}_{2} \mathrm{O}_{2}\left(\mathrm{H}_{2} \mathrm{O}\right)_{4}\right]$. In terms of the constituent sheets, we may write the formulae of epistolite and murmanite in the following way:

\begin{tabular}{l}
\multicolumn{4}{c}{ TABLE 8. PROPOSED HYDROGEN } \\
\multicolumn{3}{c}{ BONDING FOR EPISTOLITE } \\
\begin{tabular}{cccc} 
Species & $D$ & $A$ & $D-A(\AA)$ \\
\hline $\mathrm{OH}$ & $\mathrm{O}(8)$ & $\mathrm{O}(5)$ & $3.33(1)$ \\
$\mathrm{H} \mathrm{O}$ & $\mathrm{O}(10)$ & $O(3)$ & $2.99(1)$ \\
& & $O(11) \mathrm{a}$ & $2.78(2)^{*}$ \\
& & $O(11) \mathrm{b}$ & $2.85(2)^{*}$ \\
$\mathrm{H}_{2} \mathrm{O}$ & $\mathrm{O}(11)$ & $\mathrm{O}(7)$ & $3.16(2)$ \\
& & $O(10)$ & $3.06(3)$ \\
\hline
\end{tabular}
\end{tabular}

a: $x, y+1, z+1 ; b: x+1, y+1, z+1$

"these bonds are mutually exclusive.

Mineral Sheet of Octahedra Sheets of Heteropolyhedra

Epistolite $\quad \mathrm{Na}_{3} \mathrm{Ti}^{4+}(\mathrm{OH})_{2} * \mathrm{O}_{6} *{ }^{[8]} \mathrm{Na} \square \mathrm{Nb}_{2}\left(\mathrm{Si}_{2} \mathrm{O}_{7}\right)_{2} \mathrm{O}_{2} \quad(\mathrm{OH})_{2} \quad\left(\mathrm{H}_{2} \mathrm{O}\right)_{4}$

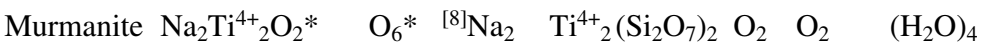

Anions indicated by stars belong to the sheet of octahedra and adjacent sheets of heteropolyhedra, hence they should not be summed from the sheet of octahedra to give the complete formula as they are counted in the sheets of heteropolyhedra.

The corresponding end-member formulae for these two minerals are as follows:
Epistolite $\quad \mathrm{Na}_{4} \mathrm{Nb}_{2} \mathrm{Ti}^{4+}\left(\mathrm{Si}_{2} \mathrm{O}_{7}\right)_{2} \mathrm{O}_{2}(\mathrm{OH})_{2}\left(\mathrm{H}_{2} \mathrm{O}\right)_{4}$

Murmanite $\mathrm{Na}_{4} \mathrm{Ti}_{4}^{4+} \quad\left(\begin{array}{lll}\left.\mathrm{Si}_{2} \mathrm{O}_{7}\right)_{2} \mathrm{O}_{4} & \left(\mathrm{H}_{2} \mathrm{O}\right)_{4}\end{array}\right.$ 


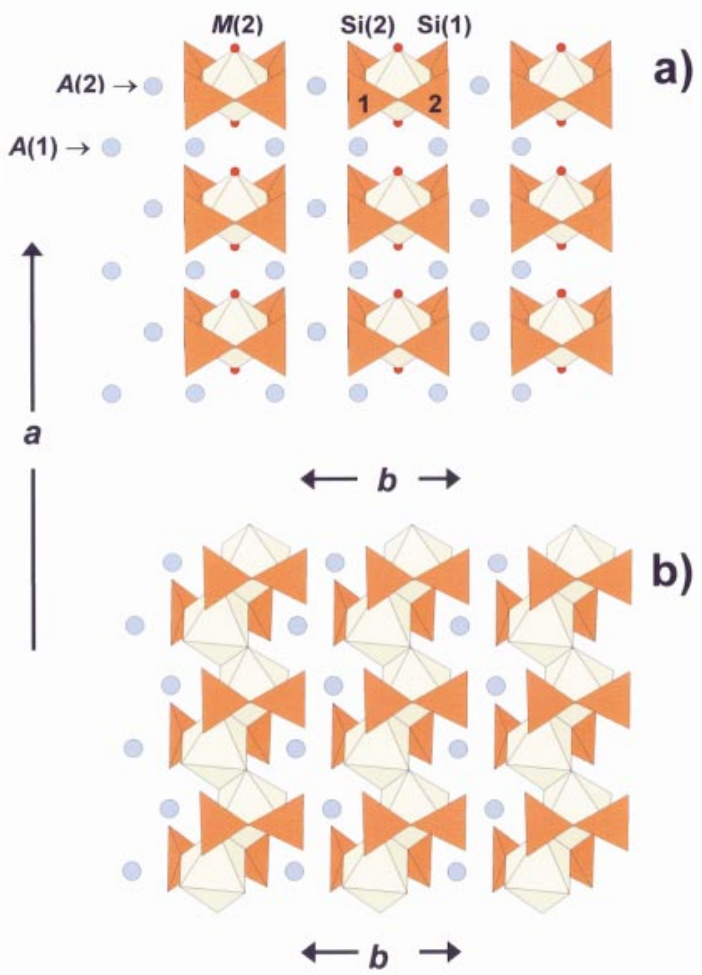

atom [O(11)]; thus the $\mathrm{O}$ atom of each $\left(\mathrm{H}_{2} \mathrm{O}\right)$ group is bonded to one cation. Hence there should be three additional bonds, two donor-hydrogen bonds of the $\left(\mathrm{H}_{2} \mathrm{O}\right)$ group, and a third hydrogen...acceptor bond from another $\left(\mathrm{H}_{2} \mathrm{O}\right)$ group. Figure 6a shows all possible $\mathrm{D}$ (donor)-A(acceptor) distances involving $\left(\mathrm{H}_{2} \mathrm{O}\right)$ groups. There is no possibility for $\mathrm{sp}^{3}$ hybridization-type hydrogen bonding within this arrangement of bonds constrained by $P \overline{1}$ symmetry. Thus we conclude that hydrogen bonding does not obey $P \overline{1}$ symmetry, whereas with $P 1$ symmetry, a stereochemically sensible scheme can be derived (Fig. 6b). There are two (mutually exclusive) D-A bonds [O(10)-O(11)a and $\mathrm{O}(10)-\mathrm{O}(11) \mathrm{b}]$ that can each occur (Table 8). For these particular bonds, the mean $D$ (donor) $-A$ (acceptor) distance is $2.97 \AA$, corresponding to weak hydrogen-bonding. The arrangement of hydrogen bonds is shown in Table 8 and Figure $6 a$. There is weak hydrogen bonding involving $(\mathrm{OH})$ groups within the TS block (Table 8, Fig. 6b), but most of the hydrogen bonds link adjacent TS blocks (Fig. 6b).

FIG. 4. Linkage of $\left[\mathrm{Si}_{2} \mathrm{O}_{7}\right]$ groups of two adjacent sheets of heteropolyhedra with $\left(\mathrm{TiO}_{6}\right)$ octahedra of the central sheet in (a) epistolite, and (b) murmanite; [6]-coordinated $\mathrm{Na}$ atoms are shown as blue circles.
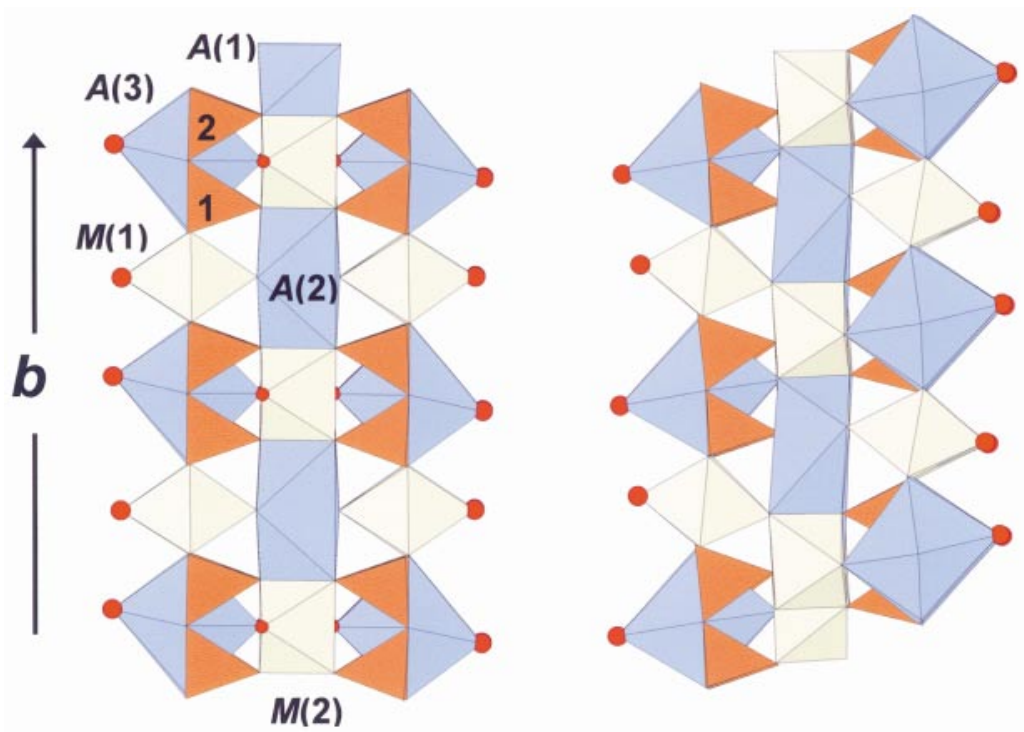

a)

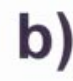

FIG. 5. Linkage of two sheets of heteropolyhedra with a sheet of octahedra within one TS block in (a) epistolite, and (b) murmanite. Legend as in Figure 3; [8]-coordinated $\mathrm{Na}$ atoms are shown as blue circles. 


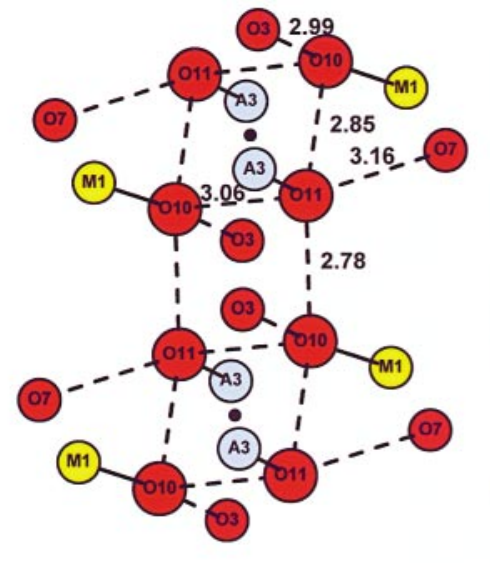

a)

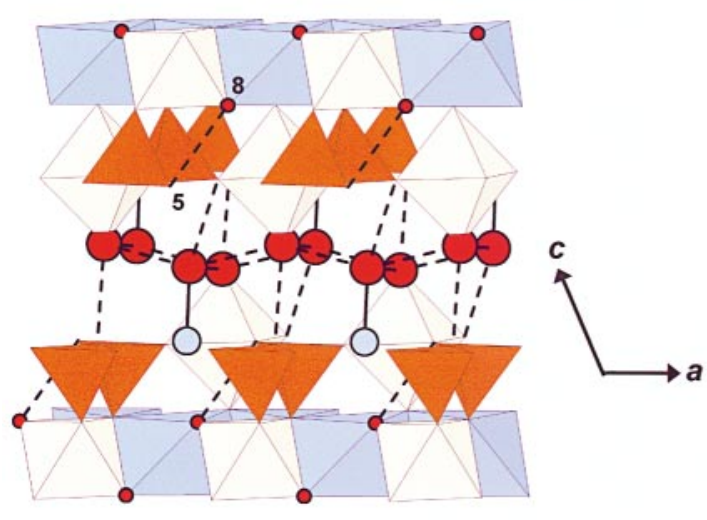

c)

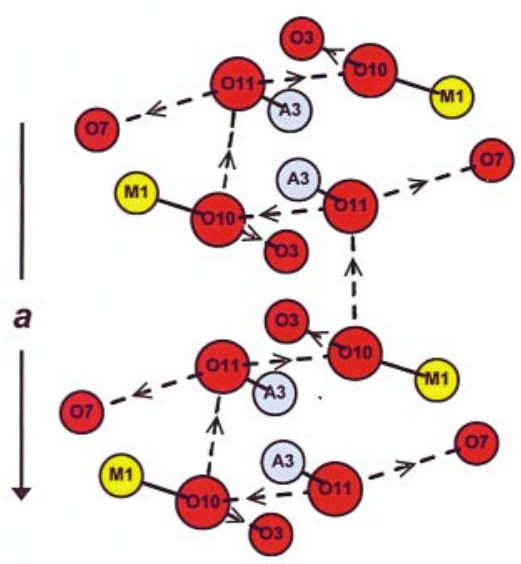

b)

FIG. 6. Proposed scheme of hydrogen bonding in epistolite: (a) all possible $\mathrm{D}-\mathrm{A}$ distances involving $\left(\mathrm{H}_{2} \mathrm{O}\right)$ groups are shown (in $\AA$ ); the black circles indicate inversion centers. (b) A general scheme of hydrogen bonding that conforms to $P 1$ symmetry. (c) An $x z$ projection of the crystal structure. Legend as in Figures 1 and $3 ;\left(\mathrm{H}_{2} \mathrm{O}\right)$ and $(\mathrm{OH})$ groups are shown as large and small red circles, [8]-coordinated $\mathrm{Na}$ atoms are shown as blue circles, possible donor (D)acceptor (A) distances are shown as dashed lines, and bonds from $A(3)$ and $M(1)$ atoms to $\left(\mathrm{H}_{2} \mathrm{O}\right)$ groups are shown as solid lines. The arrows indicate the direction from donor to acceptor anions.

Some of hydrogen bonds proposed are quite long, but as shown by Brown (1976), significant interactions still occur at such distances.

\section{SUMMARY}

(1) Epistolite and murmanite are not isostructural, despite the similarity of their formulae and unit cells. The difference between them involves the topology of their main structural unit, the TS (titanium silicate) block.
(2) The different topologies of the TS blocks result from different linkages of the central sheet of octahedra with the two adjacent sheets of heteropolyhedra. In the crystal structure of epistolite, two sheets of heteropolyhedra are approximately related by a pseudomirror plane, $m_{\mathrm{z}}$, coinciding with the plane of the sheet of octahedra. In murmanite, two sheets are shifted relative to each other.

(3) Detailed structural formulae for the TS block in epistolite and murmanite (Khalilov 1989) are as follows:

$$
\begin{aligned}
& \text { Mineral Sheet of Octahedra Sheets of Heteropolyhedra }
\end{aligned}
$$

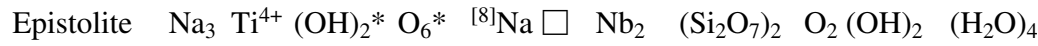

$$
\begin{aligned}
& \text { Murmanite } \mathrm{Na}_{2} \mathrm{Ti}^{4+}{ }_{2} \mathrm{O}_{2} * \quad \mathrm{O}_{6}{ }^{*}{ }^{[8]} \mathrm{Na}_{2} \quad \mathrm{Ti}^{4+}{ }_{2} \quad\left(\begin{array}{llll}
\left.\mathrm{Si}_{2} \mathrm{O}_{7}\right)_{2} & \mathrm{O}_{2} \mathrm{O}_{2} & \left(\mathrm{H}_{2} \mathrm{O}\right)_{4}
\end{array}\right.
\end{aligned}
$$


Anions indicated by stars belong to the sheet of octahedra and adjacent sheets of heteropolyhedra, hence they should not be summed (from the sheet of octahedra) to give the complete formula as they are counted in the sheets of heteropolyhedra.

(4) The ideal (end-member) chemical formula of epistolite is $\mathrm{Na}_{4} \mathrm{Nb}_{2} \mathrm{Ti}^{4+}\left(\mathrm{Si}_{2} \mathrm{O}_{7}\right)_{2} \mathrm{O}_{2}(\mathrm{OH})_{2}\left(\mathrm{H}_{2} \mathrm{O}\right)_{4}$.

(5) Murmanite and epistolite are related by the substitution $\mathrm{Ti}^{4+}{ }_{3}+\mathrm{O}^{2-}{ }_{2} \leftrightarrow \mathrm{Nb}^{5+}{ }_{2}+\square+(\mathrm{OH})_{2}^{-}$.

(6) Local decrease of symmetry from $P 1$ to $P 1$ results from hydrogen bonds of $\left(\mathrm{H}_{2} \mathrm{O}\right)$ groups located between the TS blocks.

\section{ACKNOWLEDGEMENTS}

We thank Giovanni Ferraris in particular, Ole Johnsen, Robert T. Downs and Robert F. Martin for their comments on this paper. We are very grateful to $\mathrm{S}$. Karup-Møller for a sample of epistolite from the Ilímaussaq alkaline complex, South Greenland, and to Mark Cooper for his help in finding the best possible single crystal and for collection of the X-ray data. FCH was supported by a Canada Research Chair and Major Equipment, Discovery and Major Facilities Access grants from the Natural Sciences and Engineering Research Council of Canada.

\section{REFERENCES}

BøGGILD, O.B. (1901): Epistolite, a new mineral. Medd. Grønland 24, 183-190.

BRown, I.D. (1976): Hydrogen bonding in perchloric acid hydrates. Acta Crystallogr. A32, 786-792.

(1981): The bond-valence method: an empirical approach to chemical structure and bonding. In Structure and Bonding in Crystals II (M. O'Keeffe \& A. Navrotsky, eds.). Academic Press, New York, N.Y. (1-30).

Christiansen, C.C., Makovicky, E. \& Johnsen, O. (1999): Homology and typism in heterophyllosilicates: an alternative approach. Neues Jahrb. Mineral., Abh. 175, 153-189.

Egorov-Tismenko, Yu.K. \& Sokolova, E.V. (1990): The homologous series seidozerite-nacaphite. Mineral. Zh. 12(4), 40-49 (in Russ.).

ERCit, T.S., CoOper, M.A. \& Hawthorne, F.C. (1998): The crystal structure of vuonnemite, $\mathrm{Na}_{11} \mathrm{Ti}^{4+} \mathrm{Nb}_{2}\left(\mathrm{Si}_{2} \mathrm{O}_{7}\right)_{2}$ $\left(\mathrm{PO}_{4}\right)_{2} \mathrm{O}_{3}(\mathrm{~F}, \mathrm{OH})$, a phosphate-bearing sorosilicate of the lomonosovite group. Can. Mineral. 36, 1311-1320.

FerRARIS, G. \& NÉMETH, P. (2003): Pseudo-symmetry, twinning and structural disorder in layer titanosilicates. $A b$ stracts of the 21st European Crystallographic Meeting (Durban, South Africa).
INTERNATIONAL TABLES FOR X-RAY CRYSTALLOGRAPHY (Vol. C) (1992): Kluwer, Dordrecht, The Netherlands.

KARUP-MøLLER, S. (1986a): Epistolite from the Ilímaussaq alkaline complex in South Greenland. Neues Jahrb. Mineral., Abh. 155, 289-304.

(1986b): Murmanite from the Ilímaussaq alkaline complex, South Greenland. Neues Jahrb. Mineral., Abh. 155, 67-88.

Khalilov, A.D. (1965): X-Ray Diffraction Study of the Lomonosovite - Murmanite Minerals. Ph.D. thesis, Moscow State University, Moscow, Russia (in Russ.).

(1989): Refinement of the crystal structure of murmanite and new data on its crystal chemistry. Mineral. Zh. 11(5), 19-27 (in Russ.).

MaKarov, Ye.S., Mamedov, Kh.S. \& P'yanzina, L.YA. (1965b): Crystal structure of minerals of the murmanite - lomonosovite group. Dokl. Akad. Nauk SSSR 162, 138-140.

Mamedov, Kh.S., Makarov, Ye.S. \& P'Yanzina, L.YA. (1965a): Crystal structure of murmanite. Dokl. Akad. Nauk SSSR 161, 150-152.

Pouchou, J.L. \& Pichoir, F. (1985): "PAP" ( $\phi \Omega Z)$ procedure for improved quantitative microanalysis. In Microbeam Analysis - 1985. San Francisco Press, San Francisco, California (104-106)

RastsvetaeVA, R.K. \& ANDRianov, V.I. (1986): New data on the crystal structure of murmanite. Sov. Phys. Crystallogr. 31, 44-48.

Semenov, E.I., Organova, N.I. \& KuKharchiK, M.V. (1962): New data on minerals of the lomonosovite - murmanite group. Sov. Phys. Crystallogr. 6, 746-751.

SHANNON, R.D. (1976): Revised effective ionic radii and systematic studies of interatomic distances in halides and chalcogenides. Acta Crystallogr. A32, 751-767.

SHELDRICK, G.M. (1997): SHELX-97: Program for the Solution and Refinement of Crystal Structures. Siemens Energy and Automation, Madison, Wisconsin.

(1998): SADABS User Guide. University of Göttingen, Göttingen, Germany.

SoKolova, E. \& HawthoRne, F.C. (2001): The crystal chemistry of the $\left[\mathrm{M}_{3} \phi_{11-14}\right]$ trimeric structures: from hyperagpaitic complexes to saline lakes. Can. Mineral. 39, $1275-$ 1294.

Received November 28, 2003, revised manuscript accepted March 11, 2004 